\title{
Petrology and tectonic implications of Silurian(?) metavolcanic rocks in the Clyburn Brook area and on Ingonish Island, northeastern Cape Breton Island, Nova Scotia
}

\author{
Sandra M. Barr and Robert P. Raeside \\ Department of Geology, Acadia University, Wolfville, Nova Scotia B0P IX0, Canada
}

Date Received January 22, 1998

Date Accepted April 15, 1998

\begin{abstract}
Metavolcanic rocks in the Clyburn Brook area of northeastern Cape Breton Island range in composition from mafic to felsic, include flows and tuffs, and are interlayered with less abundant semi-pelitic metasedimentary rocks. In contrast, metavolcanic rocks on nearby Ingonish Island are mainly rhyolitic flows and tuffs, and lack interlayered metasedimentary rocks. Because correlation between these two areas cannot be confirmed without more radiometric dating, continued use of separate names (Clyburn Brook formation and Ingonish Island rhyolite) is advocated.

Rocks in the Clyburn Brook formation contain greenschist facies mineral assemblages and are mainly well foliated. Although also metamorphosed, the Ingonish Island rhyolite is mainly unfoliated, and the metamorphism may be a result of contact metamorphism. A contact metamorphic overprint is also present in the Clyburn Brook formation adjacent to the ca. $402 \mathrm{Ma}$ Cameron Brook Granodiorite, and felsic dykes perhaps related to the intrusion occur in both the Clyburn Brook formation and the Ingonish Island rhyolite. These observations suggest that both units are older than ca. $402 \mathrm{Ma}$, consistent with a previously published imprecise $\mathrm{Rb}$-Sr date of $412 \pm 15 \mathrm{Ma}$ for the Ingonish Island rhyolite.

Petrochemical characteristics of mafic rocks in the Clyburn Brook formation indicate tholeiitic affinity and origin in an arc-related setting, possibly a back-arc. Although they show chemical differences, felsic rocks in both the Clyburn Brook formation and on Ingonish Island have compositions consistent with an extensional setting, possibly within a continental arc or back-arc such as the modern-day Taupo volcanic zone in New Zealand. Overall, the Clyburn Brook formation shows lithological and chemical similarity to the Money Point Group, a Silurian (ca. 430 $\mathrm{Ma}$ ) volcanic arc/back-arc unit in the Aspy terrane of Cape Breton Island, and is inferred to be of similar age.
\end{abstract}

Les roches volcaniques métamorphisées du secteur du ruisseau Clyburn dans le nord-est de l'île du Cap-Breton sont composées de roches allant de mafiques à felsiques. Elles renferment des coulées et des tufs, et elles sont interstratifiées de roches métasédimentaires semi-pélitiques moins abondantes. À l'opposé, les roches volcaniques métamorphisées de l'île voisine d'Ingonish sont principalement des coulées et des tufs rhyolitiques sans roches métasédimentaires interstratifiées. Comme les chercheurs ne peuvent pas confirmer la corrélation entre ces deux secteurs sans datation radiométrique plus poussée, ils recommandent qu'on continue à utiliser des noms séparés (formation de Clyburn Brook et rhyolite de l'île Ingonish).

Les roches de la formation de Clyburn Brook renferment des associations minéralogiques de faciès de schistes verts et elles sont passablement feuilletées. Même si la rhyolite de l'île Ingonish est elle aussi métamorphisée, elle est essentiellement non feuilletée et le métamorphisme pourrait être dû à un métamorphisme de contact. Une surimposition métamorphique de contact est également présente dans la formation de Clyburn Brook adjacente à la granodiorite d'il y a environ $402 \mathrm{Ma}$ du ruisseau Cameron, et on relève la présence de dykes felsiques sans doute reliés à l'intrusion tant dans la formation de Clyburn Brook que dans la rhyolite de l'île Ingonish. Ces observations laissent supposer que les deux unités sont antérieures à environ $402 \mathrm{Ma}$, ce qui correspondrait à la datation au Rb-Sr imprécise de 412 $\pm 15 \mathrm{Ma}$ de la rhyolite de l'île Ingonish précédemment publiée.

Les caractéristiques pétrochimiques des roches mafiques de la formation de Clyburn Brook témoignent d'une affinité tholéiitique avec un cadre associé à un arc, possiblement un arrière-arc, d'où elles proviendraient. Les roches felsiques de la formation de Clyburn Brook et de l'île Ingonish, même si elles affichent des différences chimiques, correspondent à un cadre d'extension, possiblement à l'intérieur d'un arc continental ou d'un arrière-arc, comme la zone volcanique actuelle de Taupo en Nouvelle-Zélande. La formation de Clyburn Brook présente dans son ensemble une similarité lithologique et chimique avec le groupe de la pointe Money, une unité d'arc / arrière-arc volcanique du Silurien (d'environ $430 \mathrm{Ma}$ ) dans le terrane d'Aspy sur l'île du Cap-Breton, et on la suppose d'un âge analogue.

[Traduit par la rédaction]

\section{INTRODUCTION}

Interlayered metavolcanic and metasedimentary rocks occur in the Clyburn Brook area of northeastern Cape Breton Island, and are surrounded by contrasting, higher grade metamorphic rocks and dioritic to granitic plutons (Figs. 1, 2).
Because these metavolcanic and metasedimentary rocks cannot be correlated with certainty with other units, Lin (1992, $1993,1995)$ suggested that they informally be termed the Clyburn Brook formation. He also included metavolcanic rocks offshore on nearby Ingonish Island (Fig. 2) in the formation. 


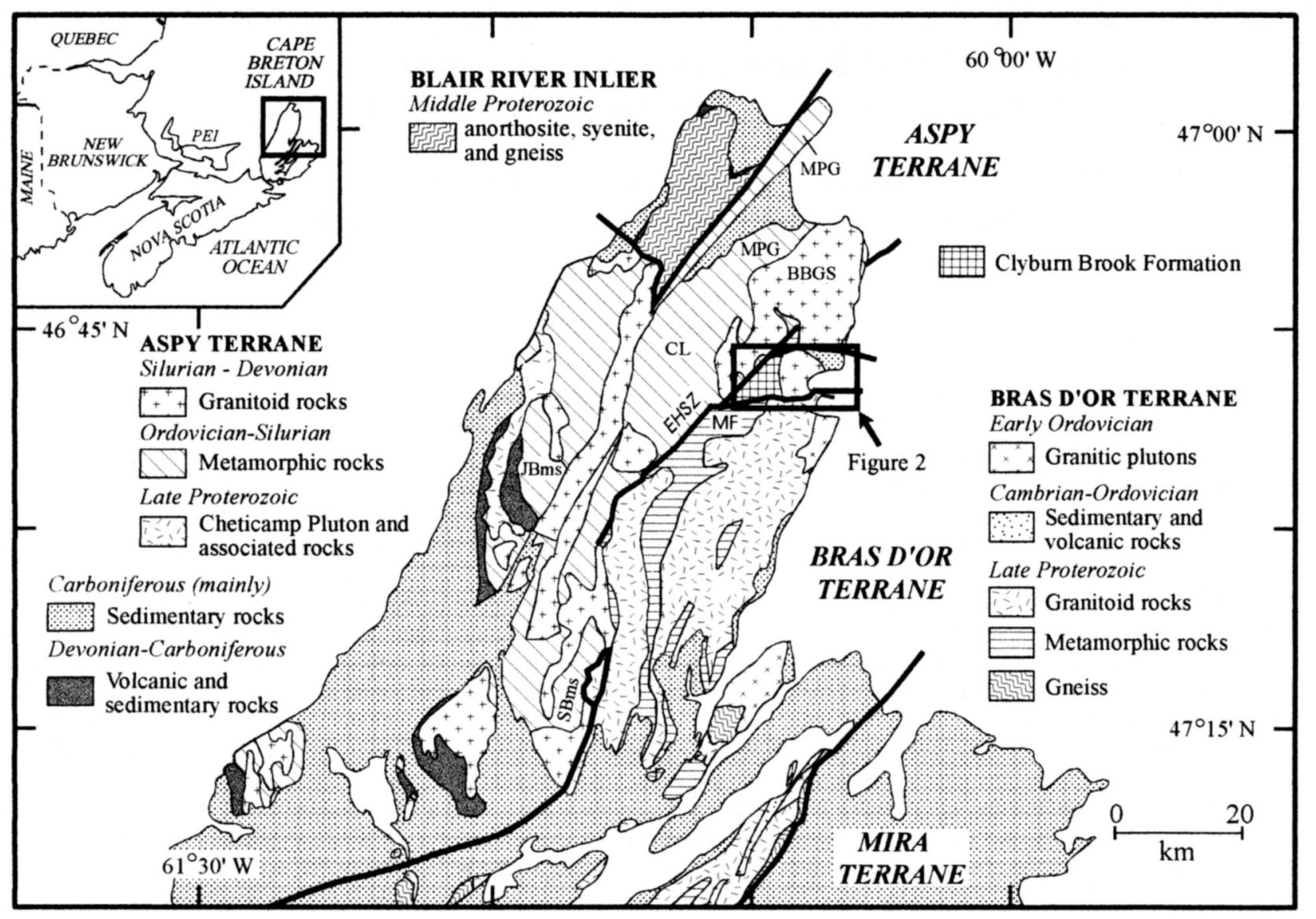

Fig. 1. Simplified geological map of northern Cape Breton Island (after Barr and Raeside, 1989), showing the location of the Clyburn Brook area. Abbreviations: MPG, Money Point Group; MF, McMillan Flowage Formation; BBGS, Black Brook Granitic Suite; JBms, Jumping Brook metamorphic suite; SBms, Sarach Brook metamorphic suite; EHSZ, Eastern Highlands shear zone.

The purpose of this paper is to present the results of a petrological study of metavolcanic rocks in the Clyburn Brook formation, including both the Clyburn Brook area and Ingonish Island. As will be shown, the Ingonish Island rocks differ petrologically from those in the Clyburn Brook area, and accordingly, it is suggested that the name Clyburn Brook formation be restricted to rocks in the Clyburn Brook area, and that the informal name Ingonish Island rhyolite be retained for the volcanic rocks on Ingonish Island, at least until the age of both units has been better established. The petrochemical data are used to assess the tectonic setting in which the rocks in both areas were formed, and to compare them to other, possibly correlative, metavolcanic rocks in the Cape Breton Highlands.

\section{Previous work and geological setting}

Metamorphic rocks in the Clyburn Brook area occupy an uncertain position in tectonostratigraphic interpretations of the Cape Breton Highlands. The minimum age is constrained by the ca. 402 Ma (Dunning et al., 1990) Cameron Brook Granodiorite (Fig. 2), which intruded the metamorphic rocks (Wiebe, 1972; Raeside and Barr, 1992; Lin, 1992), but the maximum age is not constrained. Wiebe (1972) tentatively assigned the metamorphic rocks of the Clyburn Brook area to the
Precambrian Fourchu Group, based on the abundance of volcanic rocks, whereas higher grade metamorphic rocks to the south were assigned to the George River Group, and higher grade rocks to the west were grouped as "undifferentiated metamorphic rocks". Barr and Raeside (1989) and Raeside and Barr (1992) included the rocks in the Clyburn Brook area in their Neoproterozoic McMillan Flowage Formation, although they recognized the contrast in metamorphic grade and lithology with the immediately adjacent part of the McMillan Flowage Formation to the south, which consists mainly of pelitic rocks, marble, and quartzite. They also recognized that the two areas are separated by a fault. By placing the Clyburn Brook area in the McMillan Flowage Formation, Barr and Raeside (1989) assigned the area to their Bras d'Or terrane, located southeast of the Eastern Highlands shear zone which separates Bras d'Or terrane units to the southeast from Aspy terrane units to the northwest (Figs. 1, 2).

In contrast, Lin $(1992,1993)$ made the Clyburn Brook formation a map unit, separated from the McMillan Flowage Formation by the Soapstone Brook fault (Fig. 2). He showed that the Eastern Highlands shear zone is a broad zone that affects the Clyburn Brook formation as well as metamorphic and plutonic units to the north and west. $\operatorname{Lin}(1992,1993)$ and Chen $e t$ al. (1995) proposed that the Eastern Highlands shear zone is not a terrane boundary because some units of the "Aspy terrane" originally had an unconformable relationship with 


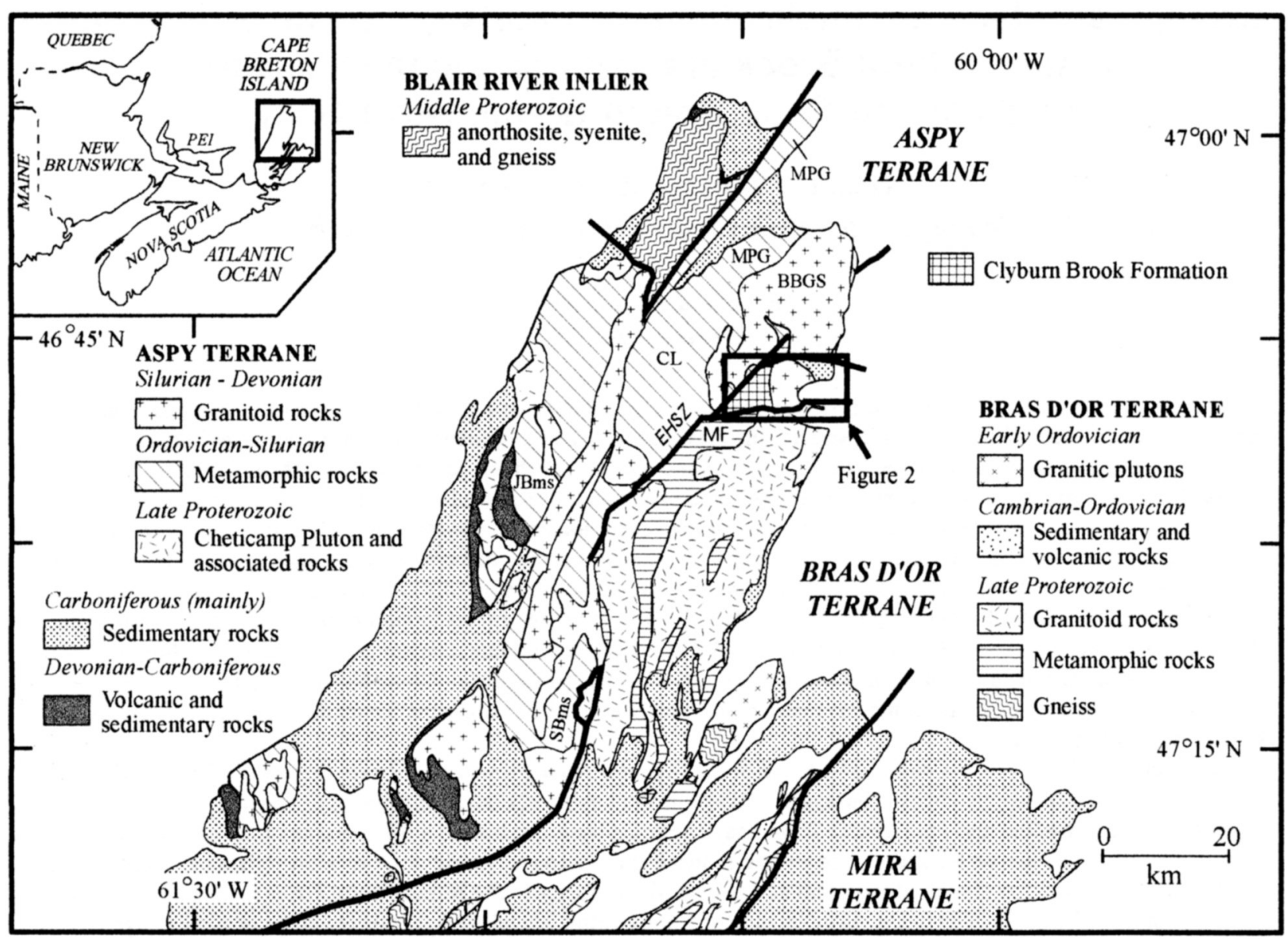

Fig. 2. Geological map showing the Clyburn Brook formation, Ingonish Island rhyolite, and surrounding units (modified from Lin, 1992 and Barr et al., 1992), with geochemical sample locations in the Clyburn Brook area (1 through 18) and on Ingonish Island (19 through 23). Sample descriptions are summarized in Appendix A. The Eastern Highlands shear zone (EHSZ) is a broad zone centred on the fault zone labelled shown on the map (Lin, 1992, 1995). SBF is the Soapstone Brook fault.

units of the "Bras d'Or terrane". Lynch and Tremblay (1992), Lynch et al. (1995), and Lynch (1996) also interpreted an unconformable relationship between the two "terranes", and correlated the Clyburn Brook formation with volcanic-sedimentary units of the Aspy terrane.

Volcanic rocks on Ingonish Island were included in the Fourchu Group by Wiebe (1972). However, based on their lack of similarity to metavolcanic rocks in the Clyburn Brook area, Raeside and Barr (1992) assigned them to a separate unit, the Ingonish Island rhyolite, with an inferred Silurian age. The age assignment was based in part on the $\mathrm{Rb}$-Sr isochron age of $412 \pm 15 \mathrm{Ma}$ reported for a suite of five samples from Ingonish Island by Keppie and Halliday (1986). The authors also showed that a rhyolite sample from the Clyburn Brook area plots near the isochron defined by the Ingonish Island samples, but concluded that the similarity may be fortuitous because the Clyburn Brook sample is more metamorphosed and deformed, and unlikely to be as young as the Ingonish Island rhyolite. The same Clyburn Brook rhyolite subsequently yielded a U-Pb (zircon) age which indicated that it is an intrusion (dyke or sill) into the Clyburn Brook formation, rather than a flow (J.D. Keppie, written communication to J.B. Murphy, 1996). However, this age, presumably similar to or younger than the ca. $402 \mathrm{Ma}$ age of the Cameron Brook Granodiorite, has yet to be published. Observations by the present authors show that relatively unmetamorphosed felsic dykes are fairly common in the Clyburn Brook area, and in the metavolcanic rocks on Ingonish Island, as described below.

Lin (1993) noted evidence for deformation and metamorphism in the Ingonish Island rhyolite, and suggested that it may be part of the Clyburn Brook formation. Potassium feldspar from the Ingonish Island rhyolite has yielded preliminary ${ }^{40} \mathrm{Ar} /{ }^{39} \mathrm{Ar}$ ages of ca. 380 to $360 \mathrm{Ma}$ (P. Reynolds, personal communication, 1997), which probably indicates the time of cooling through the closure temperature for potassium feldspar.

In this paper, the rocks in the Clyburn Brook area and on Ingonish Island are described separately.

\section{Field Relations AND lithology}

\section{Clyburn Brook area}

The Clyburn Brook formation in the Clyburn Brook area is intruded on the east by the Cameron Brook Granodiorite, which has been dated at $402 \pm 3 \mathrm{Ma}$ (U-Pb zircon and titanite; Dunning et al., 1990). Hence this date provides a minimum 
age for the formation. The southern margin of the formation is faulted against metamorphic rocks of the McMillan Flowage Formation, the ca. $560 \mathrm{Ma}$ (Dunning et al., 1990) Ingonish River Tonalite, and unnamed gneissic rocks (Fig. 2). The main fault in this area was termed the Clyburn Brook fault by Raeside and Barr (1992) but renamed the Soapstone Brook fault by Lin $(1992,1993)$.

The western margin of the Clyburn Brook formation is part of the broad Eastern Highlands shear zone (Lin, 1993), and also a later more restricted shear zone (D2 of Lin, 1993). In this area, the Clyburn Brook formation is juxtaposed by faults against the higher grade Cheticamp Lake Gneiss of the Aspy terrane of Barr and Raeside (1989), or against varied dioritic and amphibolitic rocks of uncertain affinity (Lin, 1993; Barr and Raeside, 1994).

Metavolcanic rocks in the Clyburn Brook area range from mafic to felsic and include both flows and tuffs. Relict igneous features such as phenocrysts, amygdules, and intergranular textures are commonly preserved, especially in felsic samples. However, mineral assemblages are indicative of greenschist facies metamorphism, and dominated by albitic plagioclase, chlorite, and epidote in mafic and intermediate samples, and albitic plagioclase, quartz, muscovite, and epidote in felsic samples. The minerals define a weak to moderate foliation in most samples. Interlayered metasedimentary rocks are mainly slate and phyllite with granoblastic quartz and abundant lepidoblastic muscovite and biotite. Garnet is present in a few samples. In the vicinity of the Cameron Brook Granodiorite, contact metamorphism has produced abundant biotite and amphibole in mafic rocks and porphyroblasts of cordierite and andalusite(?) in metasedimentary rocks. As also noted by Lin (1992), the rocks were deformed after contact metamorphism because the porphyroblasts are deformed.

Evidence of deformation is heterogeneous, and concentrated in the metasedimentary layers which are strongly foliated. The foliation trends mainly northeasterly, with steep dips (Lin, 1992). As described by Lin (1992), bedding, where recognizable, is tightly to isoclinally folded, and the foliation is axial planar to these folds. Lin (1992) attributed the deformation to shearing under greenschist facies conditions.

\section{Ingonish Island}

Volcanic rocks comprise most of Ingonish Island, unconformably overlain on the southwest (Fig. 2) by small areas of carbonate rocks of the Gays River Formation of the Carboniferous Windsor Group (van der Gaag et al., 1996). The volcanic rocks are mainly rhyodacitic flows and tuffs, intruded by cross-cutting dykes of pink porphyritic rhyolite.

The rhyodacitic flows and tuffs differ in appearance from metavolcanic rocks in the Clyburn Brook area. They are dark grey to black, and show well-preserved flow-banding. Cleavage is present only locally, and may be related to small shear zones. In thin section, the rocks show evidence for low-grade metamorphism such as would be caused by thermal overprinting, perhaps due to the nearby Cameron Brook Granodiorite, or possibly the Black Brook Granitic Suite. Tuffaceous samples contain clasts of mainly fine-grained to cryptocrystal- line felsic composition. Flow samples are mainly cryptocrystalline to felty masses of feldspar and quartz, with scattered mica flakes.

The rhyolitic dykes consist of plagioclase and anorthoclase phenocrysts in a trachytic groundmass. Scattered biotite and muscovite flakes appear to be of igneous origin, based on texture. In contrast to the host volcanic rocks, they show little evidence of recrystallization or metamorphism.

\section{GeOChemistry}

Twenty-three representative samples were analyzed for major and trace elements (Table 1), including eighteen from the Clyburn Brook area and five from Ingonish Island (Appendix A). The analysed samples from the Clyburn Brook area range from mafic to felsic, but are mainly of basalt to basaltic andesite or rhyodacite to rhyolite composition (Fig. $3 \mathrm{a}, \mathrm{b})$; only one sample has a $\mathrm{SiO}_{2}$ content between $56 \%$ and $68 \%$ (Fig. 3a). The relatively low $\mathrm{Nb} / \mathrm{Y}$ ratios of the samples indicate that they are subalkalic (Fig. 3b).

On the $\mathrm{Nb}-\mathrm{Zr}-\mathrm{Y}$ discrimination diagram for mafic rocks, the mafic samples plot mainly in the overlapping fields for within-plate basalt, volcanic-arc basalt, and normal mid-ocean ridge basalt (N-MORB) (Fig. 4a). However, based on the Ti$\mathrm{Zr}-\mathrm{Y}$ diagram, the within-plate setting seems unlikely, and the samples lie mainly in the calc-alkalic basalt field, or in the overlapping island-arc tholeiite, MORB, and calc-alkalic basalt fields (Fig. 4b). Tholeiitic, rather than calc-alkalic, affinity is suggested by a plot of $\mathrm{TiO}_{2}$ vs. $\mathrm{FeO} / \mathrm{MgO}$ (Fig. 5). A multielement variation diagram for the mafic samples shows wider variation in the more mobile elements such as $\mathrm{Sr}, \mathrm{K}, \mathrm{Rb}$, and $\mathrm{Ba}$, and less variation in the typically less mobile elements such as $\mathrm{Nb}, \mathrm{P}, \mathrm{Zr}, \mathrm{Ti}, \mathrm{Y}$, and $\mathrm{V}$ (Fig. 6). The pattern for the latter elements is intermediate between that of the average volcanicarc tholeiite, which shows more pronounced depletion in $\mathrm{Nb}$, $\mathrm{Zr}$, and $\mathrm{Ti}$, and the average within-plate tholeiite, which has higher values of these elements. This intermediate character is consistent with an extensional environment within or associated with an arc, such as a back-arc basin or marginal basin. The abundance of sedimentary rocks interbedded with the volcanic rocks is also consistent with that setting.

The felsic samples from the Clyburn Brook area are mainly higher in $\mathrm{SiO}_{2}$ (more rhyolitic) than those from Ingonish Island (Fig. 3a). On a tectonic setting discrimination diagram for felsic rocks, the felsic samples from the Clyburn Brook area plot mainly in the volcanic-arc field, whereas the Ingonish Island volcanic samples plot at the margin of the within-plate granite field (Fig. 7). On a multi-element variation diagram, normalized against the average A-type granite of Whalen $e t$ al. (1987), the felsic samples from the Clyburn Brook area show wide variation (Fig. 8a). Compared to the average Atype granite, they tend to be enriched in $\mathrm{Sr}$ and $\mathrm{P}$, and depleted in $\mathrm{Zr}$ and $\mathrm{Y}$, characteristics of the average felsic I-type granite of Whalen et al. (1987), as shown for comparison on Figure 8a. In contrast, the rhyolite samples from Ingonish Island are enriched in $\mathrm{Ba}$ and do not show Sr enrichment, and hence are less similar to the average felsic I-type granite (Fig. 
Table 1. Major and trace element data ${ }^{1}$ for samples from the Clyburn Brook formation and Ingonish Island

\begin{tabular}{|c|c|c|c|c|c|c|c|c|c|c|c|c|c|c|c|c|c|c|c|c|c|c|c|}
\hline Sample & $\begin{array}{c}1 \\
\text { SB3 } 104\end{array}$ & $\mathrm{cw}^{2} 3616$ & $\begin{array}{c}3 \\
\mathrm{CW} 3618\end{array}$ & $\stackrel{4}{\mathrm{CW} 362 \mathrm{i}}$ & $\begin{array}{c}5 \\
\mathrm{CW} 3625\end{array}$ & $\begin{array}{c}6 \\
\text { CW3629 }\end{array}$ & $\begin{array}{c}7 \\
\mathrm{CW} 3640\end{array}$ & $\begin{array}{c}8 \\
\mathrm{CW} 3641\end{array}$ & $\stackrel{9}{\mathrm{RR} 2582}$ & $\begin{array}{c}10 \\
\text { RW90 }\end{array}$ & $\begin{array}{l}11 \\
\text { SLCB32 }\end{array}$ & $\begin{array}{c}12 \\
\text { SB3101 }\end{array}$ & $\begin{array}{c}13 \\
\text { SL91-1 }\end{array}$ & $\begin{array}{c}14 \\
\text { SLCB39 }\end{array}$ & $\begin{array}{c}15 \\
\text { SB3103 }\end{array}$ & $\begin{array}{c}16 \\
\text { CW3643 }\end{array}$ & $\begin{array}{c}17 \\
\text { RR2577 }\end{array}$ & $\begin{array}{c}18 \\
\text { RR2579 }\end{array}$ & $\begin{array}{c}19 \\
\text { RR2630 }\end{array}$ & $\begin{array}{c}20 \\
\text { RR2631 }\end{array}$ & $\begin{array}{c}21 \\
\text { RR2632 }\end{array}$ & $\begin{array}{c}22 \\
\text { RR2634 }\end{array}$ & $\begin{array}{c}23 \\
\text { RR2638 }\end{array}$ \\
\hline \multicolumn{24}{|l|}{ wt. \% } \\
\hline $\begin{array}{l}\mathrm{SiO}_{2} \\
\mathrm{TiO}_{2}\end{array}$ & $\begin{array}{r}50.89 \\
2.23\end{array}$ & $\begin{array}{r}48.82 \\
19\end{array}$ & $\begin{array}{r}52.63 \\
105\end{array}$ & $\begin{array}{r}46.25 \\
1.25\end{array}$ & 50.65 & 48.03 & 50.02 & 48.20 & 50.08 & 51.38 & 52.38 & 65.36 & 55.39 & 69.68 & 70.37 & 77.06 & 74.03 & 75.22 & 71.73 & 68.84 & 71.12 & 69.40 & 69.25 \\
\hline $\begin{array}{l}\mathrm{TiO}_{2} \\
\mathrm{Al}_{2} \mathrm{O}_{3}\end{array}$ & $\begin{array}{r}2.23 \\
14.60\end{array}$ & $\begin{array}{r}1.19 \\
16.89\end{array}$ & $\begin{array}{r}1.05 \\
15.31\end{array}$ & $\begin{array}{r}1.35 \\
1669\end{array}$ & $\begin{array}{r}1.24 \\
1567\end{array}$ & 1.77 & $\begin{array}{r}1.53 \\
\end{array}$ & 1.61 & 1.14 & 1.12 & 1.08 & 0.68 & 2.19 & 0.33 & 0.49 & 0.30 & 0.12 & 0.12 & 0.31 & 0.44 & 0.43 & 0.48 & 0.45 \\
\hline $\mathrm{Fe}_{2} \mathrm{O}_{3}^{\mathrm{T}}$ & 12.81 & 9.49 & $\begin{array}{r}15.31 \\
8.86\end{array}$ & $\begin{array}{l}16.69 \\
10.73\end{array}$ & $\begin{array}{r}15.67 \\
9.18\end{array}$ & $\begin{array}{l}16.98 \\
11.48\end{array}$ & $\begin{array}{l}15.93 \\
1160\end{array}$ & $\begin{array}{r}18.73 \\
8.64\end{array}$ & $\begin{array}{r}18.31 \\
8.66\end{array}$ & 17.64 & $\begin{array}{r}16.67 \\
8.45\end{array}$ & 15.95 & 16.27 & 15.88 & 14.79 & 11.61 & 13.91 & 14.23 & 15.70 & 14.33 & 13.34 & 14.92 & 14.85 \\
\hline $\mathrm{MnO}$ & 0.18 & 0.18 & $\begin{array}{l}.8 .80 \\
0.16\end{array}$ & $\begin{array}{r}10.73 \\
0.15\end{array}$ & $\begin{array}{l}9.18 \\
0.15\end{array}$ & $\begin{array}{r}11.48 \\
0.18\end{array}$ & $\begin{array}{r}11.60 \\
0.24\end{array}$ & $\begin{array}{l}8.64 \\
0.18\end{array}$ & $\begin{array}{l}8.66 \\
0.15\end{array}$ & $\begin{array}{r}11.46 \\
0.18\end{array}$ & 8.45 & 3.73 & 8.89 & 1.68 & 2.07 & 1.70 & 1.09 & 1.26 & 1.65 & 4.53 & 4.48 & 4.93 & 4.79 \\
\hline $\mathrm{MgO}$ & 6.37 & 5.94 & 7.09 & 9.47 & 4.64 & 7.25 & 5.65 & 2.11 & 5.79 & $\begin{array}{l}0.18 \\
5.54\end{array}$ & & 0.06 & 0.16 & 0.03 & 0.09 & 0.04 & 0.05 & 0.06 & 0.02 & 0.15 & 0.17 & 0.19 & 0.16 \\
\hline $\mathrm{CaO}$ & 6.76 & 8.50 & 7.26 & 8.21 & 6.72 & 6.51 & 9.67 & 16.58 & 8.04 & 5.02 & $\begin{array}{l}7.98 \\
4.47\end{array}$ & $\begin{array}{l}2.41 \\
3.00\end{array}$ & $\begin{array}{l}2.76 \\
4.67\end{array}$ & $\begin{array}{l}0.69 \\
158\end{array}$ & $\begin{array}{l}1.20 \\
1.28\end{array}$ & 1.30 & 0.88 & 0.22 & 1.27 & 0.85 & 0.81 & 1.17 & 0.87 \\
\hline $\mathrm{Na}_{2} \mathrm{O}$ & 3.38 & 2.69 & 2.75 & 2.76 & 2.79 & 3.86 & 2.77 & 1.92 & 3.13 & 3.06 & 0.43 & $\begin{array}{l}5.00 \\
3.99\end{array}$ & $\begin{array}{l}4.67 \\
5.81\end{array}$ & $\begin{array}{l}1.38 \\
4.55\end{array}$ & $\begin{array}{l}1.28 \\
4.44\end{array}$ & 1.71 & 0.49 & 0.97 & 0.84 & 0.11 & 0.26 & 0.44 & 0.24 \\
\hline $\mathrm{K}_{2} \mathrm{O}$ & 0.58 & 0.17 & 1.06 & 0.72 & 1.56 & 0.05 & 0.68 & 0.14 & 0.48 & 0.44 & 3.31 & 3.07 & 0.22 & 2.39 & $\begin{array}{l}4.44 \\
3.92\end{array}$ & $\begin{array}{l}4.06 \\
0.60\end{array}$ & 4.24 & 2.19 & 3.45 & 5.11 & 4.61 & 6.42 & 5.51 \\
\hline $\mathrm{P}_{2} \mathrm{O}_{5}$ & 0.26 & 0.19 & 0.26 & 0.23 & 0.20 & 0.18 & 0.42 & 0.47 & 0.19 & 0.19 & 0.20 & 025 & $\begin{array}{l}0.22 \\
104\end{array}$ & 0.11 & $\begin{array}{l}3.92 \\
0.09\end{array}$ & $\begin{array}{l}0.60 \\
0.05\end{array}$ & 4.10 & 2.79 & 4.53 & 4.53 & 3.97 & 2.26 & 3.63 \\
\hline LOI & 1.10 & 5.10 & 2.80 & 2.80 & 7.60 & 2.90 & 0.50 & 1.30 & 2.90 & 4.10 & 5.40 & 1.10 & $\begin{array}{l}1.04 \\
2.50\end{array}$ & 2.60 & 0.40 & $\begin{array}{l}0.05 \\
0.50\end{array}$ & 0.03 & 0.04 & 0.10 & 0.07 & 0.10 & 0.10 & 0.09 \\
\hline Total & 99.16 & 99.16 & 99.23 & 99.36 & 100.40 & 99.19 & 99.01 & 99.88 & $\mathbf{9 8 . 8 7}$ & 100.13 & 100.55 & 99.60 & 99.90 & 99.52 & 99.14 & $\begin{array}{r}0.50 \\
98.93\end{array}$ & $\begin{array}{r}1.00 \\
99.94\end{array}$ & $\begin{array}{r}2.00 \\
9910\end{array}$ & $\begin{array}{r}0.90 \\
0050\end{array}$ & $\begin{array}{r}0.30 \\
0936\end{array}$ & $\begin{array}{r}0.00 \\
09\end{array}$ & 0.20 & 0.10 \\
\hline \multirow{2}{*}{\multicolumn{24}{|c|}{$\begin{array}{l}\mathrm{ppm} \\
\mathrm{Ba}\end{array}$}} \\
\hline $\mathrm{Ba}$ & & & & & 197 & 61 & 141 & 35 & 215 & 118 & 700 & 706 & 84 & 496 & 839 & & & & & & & & \\
\hline Rb & 19 & 5 & 23 & 26 & 60 & 5 & 16 & 3 & 14 & 15 & 112 & 116 & 8 & 108 & 142 & 26 & 158 & 139 & 51 & $\begin{array}{r}2434 \\
96\end{array}$ & $\begin{array}{r}1907 \\
102\end{array}$ & $\begin{array}{r}1225 \\
49\end{array}$ & 2103 \\
\hline Sr & 366 & 348 & 589 & 323 & 167 & 194 & 324 & 441 & 515 & 435 & 78 & 600 & 142 & 271 & 161 & 290 & 87 & 94 & 226 & 22 & 36 & $\begin{array}{l}49 \\
28\end{array}$ & $\begin{array}{l}93 \\
29\end{array}$ \\
\hline $\mathrm{Y}$ & 29 & 31 & 31 & 23 & 23 & 31 & 33 & 31 & 27 & 30 & 27 & 11 & 69 & 7 & 32 & 35 & 24 & 22 & 14 & 38 & 47 & 41 & $\begin{array}{l}29 \\
43\end{array}$ \\
\hline $\mathrm{Zr}$ & 140 & 131 & 170 & 116 & 111 & 120 & 200 & 209 & 132 & 166 & 180 & 236 & 324 & 166 & 309 & 254 & 130 & 119 & 185 & 251 & 338 & 362 & 364 \\
\hline $\mathrm{Nb}$ & 6 & 5 & 7 & 8 & 5 & 5 & 10 & 11 & 5 & 8 & 8 & 7 & 14 & 5 & 14 & 18 & 22 & 20 & 8 & 21 & 19 & 20 & 21 \\
\hline Th & nd & 10 & 10 & nd & 10 & 10 & 4 & nd & 10 & 10 & 10 & 19 & 10 & 21 & 11 & 19 & 42 & 31 & 29 & 5 & 13 & 13 & 18 \\
\hline Pb & $\begin{array}{r}1 \\
21\end{array}$ & $\begin{array}{l}21 \\
18\end{array}$ & 10 & 6 & 10 & 10 & 18 & 18 & 13 & 12 & 10 & 21 & 11 & 10 & 16 & 18 & 43 & 11 & 15 & 17 & 19 & 19 & 22 \\
\hline $\begin{array}{l}\text { Ga } \\
\mathrm{Zn}\end{array}$ & $\begin{array}{r}21 \\
114\end{array}$ & $\begin{array}{l}18 \\
74\end{array}$ & $\begin{array}{l}17 \\
79\end{array}$ & 16 & 17 & 17 & 19 & 28 & 17 & 21 & 17 & 20 & 18 & 20 & 16 & 17 & 20 & 22 & 22 & 20 & 16 & 22 & 18 \\
\hline $\begin{array}{l}\mathrm{Zn} \\
\mathrm{Cu}\end{array}$ & $\begin{array}{r}114 \\
31\end{array}$ & $\begin{array}{l}14 \\
37\end{array}$ & $\begin{array}{l}79 \\
46\end{array}$ & $\begin{array}{l}99 \\
78\end{array}$ & $\begin{array}{r}102 \\
17\end{array}$ & 88 & 100 & 48 & 94 & 105 & 69 & 61 & 114 & 26 & 65 & 64 & 33 & 51 & 47 & 54 & 92 & 84 & 103 \\
\hline $\begin{array}{l}\mathrm{Cu} \\
\mathrm{Ni}\end{array}$ & $\begin{array}{l}31 \\
20\end{array}$ & $\begin{array}{r}37 \\
111\end{array}$ & $\begin{array}{r}46 \\
117\end{array}$ & $\begin{array}{l}78 \\
82\end{array}$ & $\begin{array}{r}17 \\
102\end{array}$ & 30 & 47 & 86 & 63 & 25 & 26 & 10 & 8 & 12 & nd & 11 & nd & 5 & 3 & 1 & nd & 2 & 3 \\
\hline $\begin{array}{l}N_{1} \\
V\end{array}$ & $\begin{array}{r}20 \\
484\end{array}$ & $\begin{array}{l}111 \\
227\end{array}$ & $\begin{array}{l}117 \\
215\end{array}$ & $\begin{array}{r}82 \\
242\end{array}$ & 102 & 92 & 37 & 28 & 75 & 42 & 128 & 37 & 5 & 5 & 27 & 18 & 20 & 5 & 20 & 21 & 27 & 24 & 28 \\
\hline $\mathrm{Cr}$ & $\begin{array}{r}484 \\
40\end{array}$ & $\begin{array}{l}221 \\
273\end{array}$ & $\begin{array}{l}115 \\
340\end{array}$ & $\begin{array}{l}422 \\
340\end{array}$ & $\begin{array}{l}232 \\
234\end{array}$ & 318 & 307 & 335 & 231 & 337 & 203 & 71 & 111 & 34 & 35 & 8 & 2 & 6 & 29 & 5 & 5 & 5 & 5 \\
\hline & & 213 & 340 & 340 & 234 & 259 & 146 & 51 & 145 & 172 & 313 & 73 & 5 & 14 & 4 & 22 & 7 & 5 & 14 & 13 & 12 & 9 & 5 \\
\hline
\end{tabular}

'Analyses by X-Ray Fluorescence at the Nova Scotia Regional Geochemical Centre, Saint Mary's University, Halifax.

Abbreviations: $\mathrm{LOI}$, loss-on-ignition; $\mathrm{Fe}_{2} \mathrm{O}_{3}{ }^{\mathrm{T}}$, total $\mathrm{Fe}$ as $\mathrm{Fe}_{2} \mathrm{O}_{3}$; nd, not determined.
Sample locations 1 through 23 are shown on Figure 2 . 

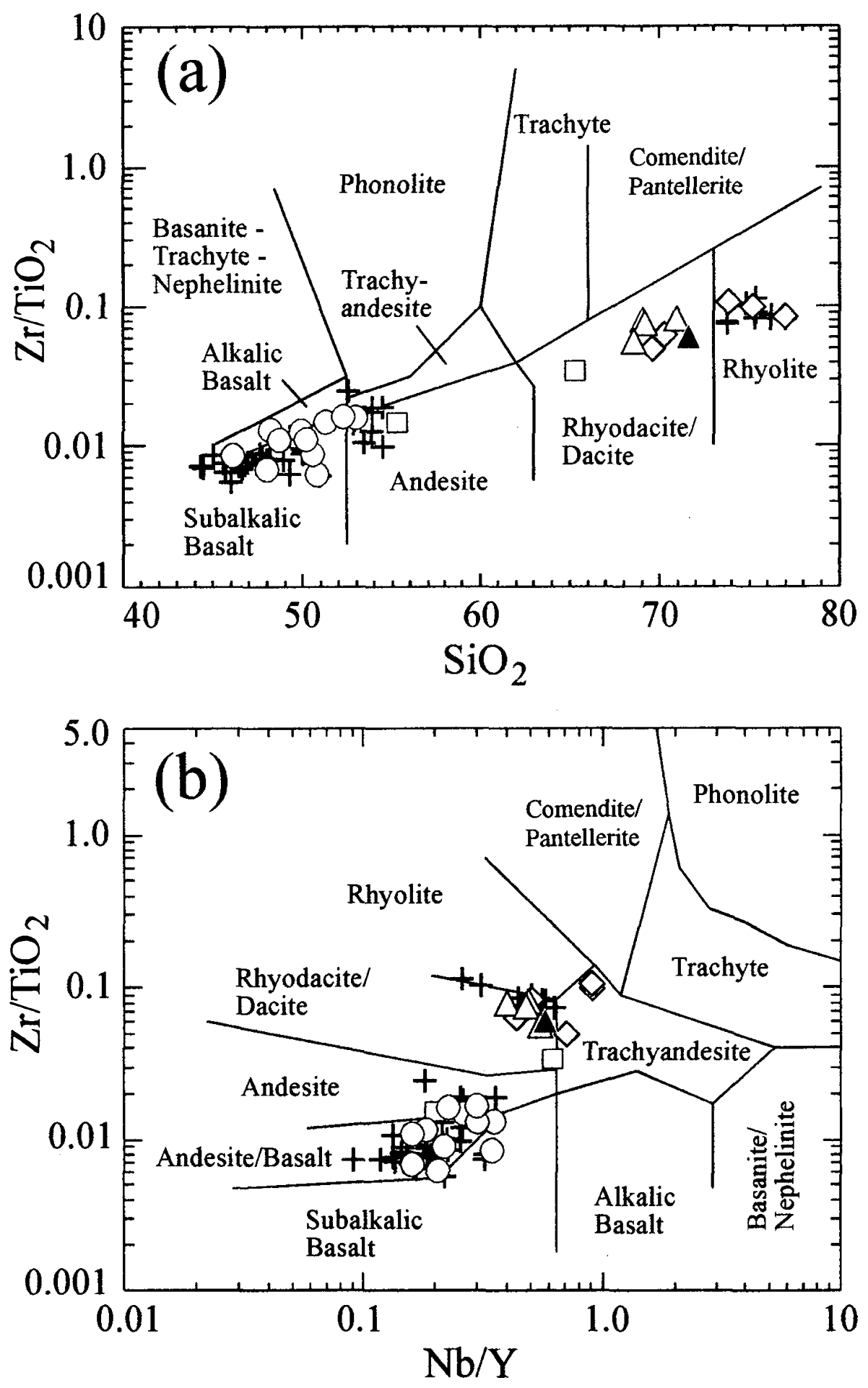

CLYBURN BROOK AREA

$\bigcirc$ mafic $(n=11)$

$\square$ intermediate $(\mathrm{n}=2)$

$\diamond$ felsic $(n=5)$
INGONISH ISLAND

$\triangle$ felsic flows/tuffs $(n=4)$

$\Delta$ felsic dyke $(n=1)$

MONEY POINT GROUP

$$
+(n=32)
$$

Fig. 3. Plots of (a) $\mathrm{Zr} / \mathrm{TiO}_{2}$ against $\mathrm{SiO}_{2}$ and (b) $\mathrm{Zr} / \mathrm{TiO}_{2}$ against $\mathrm{Nb} / \mathrm{Y}$, with fields from Winchester and Floyd (1977), for samples from the Clyburn Brook area and Ingonish Island (this study, Table 1), and the Money Point Group (data from Wunapeera, 1992; Keppie et al., 1997). 

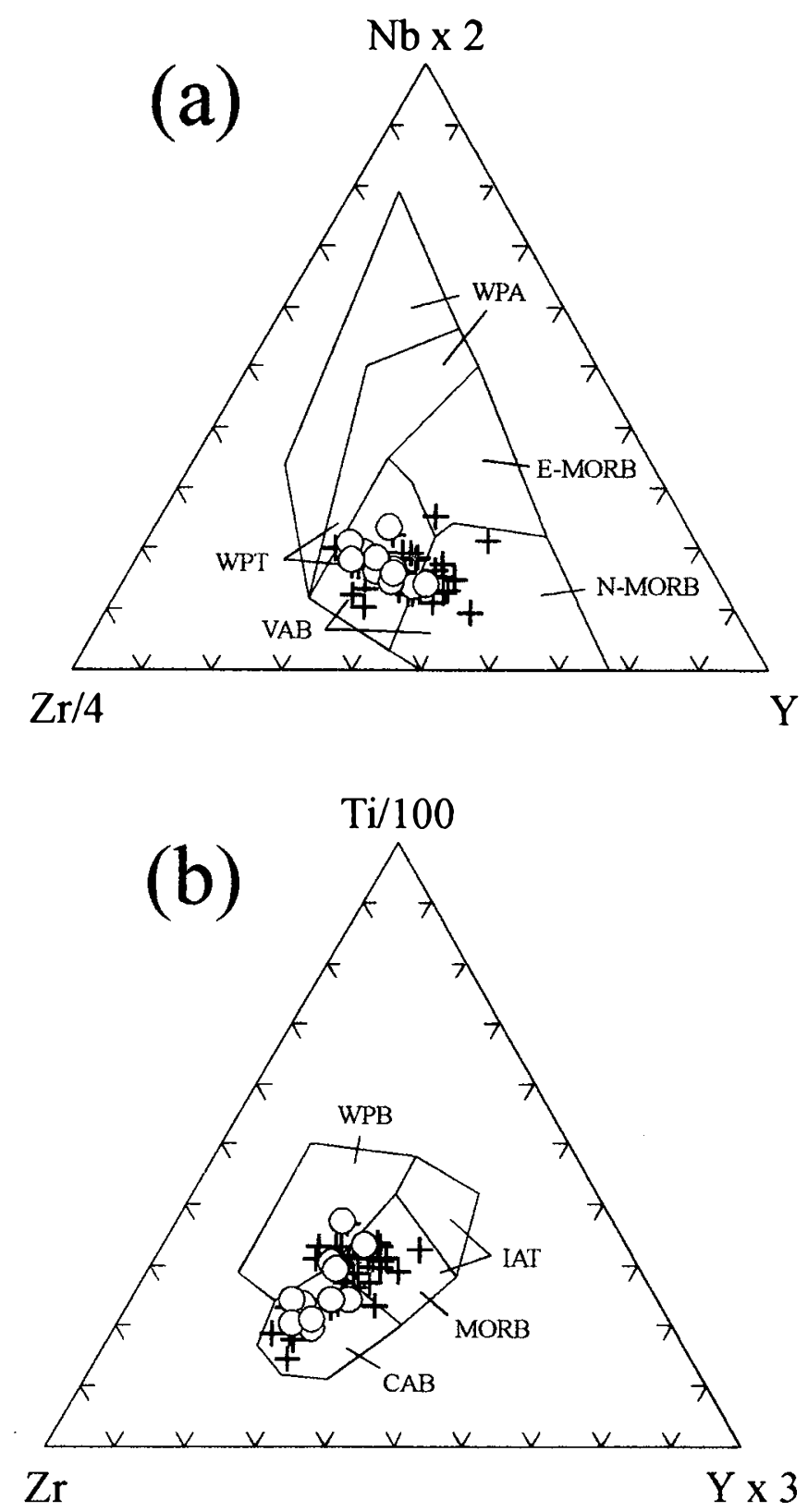

Fig. 4. Mafic samples from the Clyburn Brook area plotted on (a) $\mathrm{Nb}-\mathrm{Zr}-\mathrm{Y}$ and (b) Ti-Zr-Y discrimination diagrams. Symbols are as for mafic samples in Figure 3. Shaded field includes 34 mafic metavolcanic samples from the Money Point Group (data from Wunapeera, 1992; Keppie et al., 1997). Fields in (a) are from Meschede (1986), and in (b) from Pearce and Cann (1973). Abbreviations in (a): WPA, within-plate alkalic basalt; E-MORB, enriched mid-ocean ridge basalt; N-MORB, normal mid-ocean ridge basalt; VAB, volcanic-arc basalt; WPT, within-plate tholeiite. Abbreviations in (b): WPB, within-plate basalt; MORB, midocean ridge basalt; IAT, island-arc tholeiite; $\mathrm{CAB}$, calc-alkalic basalt.

8b), although the reliability of these differences in relatively "mobile" elements could be questioned. The felsic dyke sample from Ingonish Island is different from its host rhyolite, and more similar to the Clyburn Brook area samples (Figs. 7, $8 b)$. The petrogenetic significance of these differences is unclear, but combined with the absence of mafic volcanic and

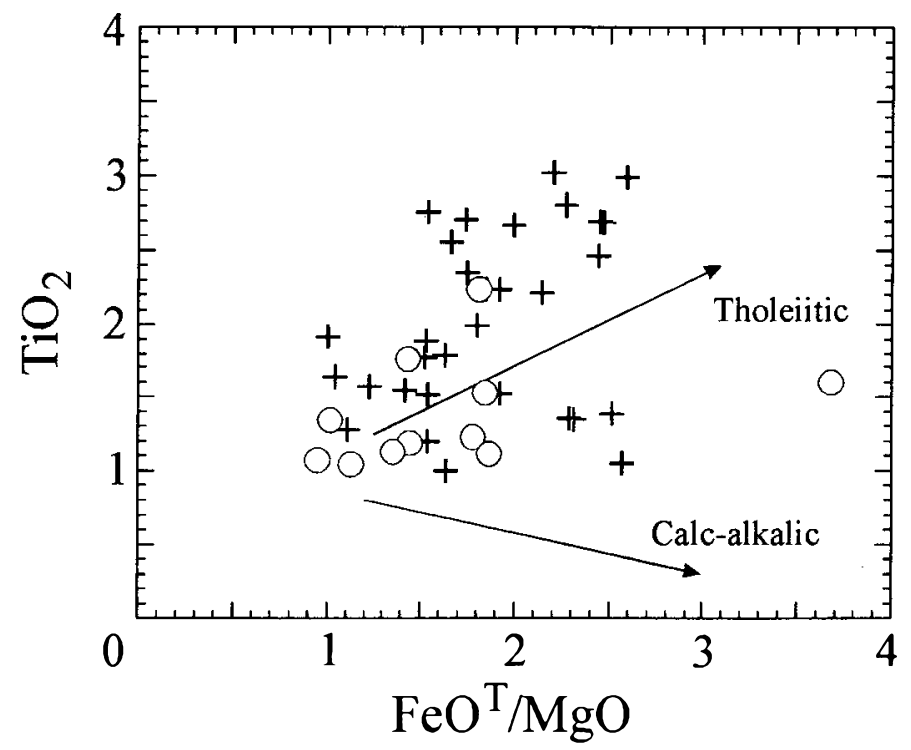

Fig. 5. Plot of $\mathrm{TiO}_{2}$ against $\mathrm{FeO}^{\mathrm{T}} / \mathrm{MgO}$ for mafic samples from the Clyburn Brook formation and Money Point Group (symbols and data sources as in Fig. 3). Typical tholeiitic and calc-alkalic trends are after Miyashiro (1974).

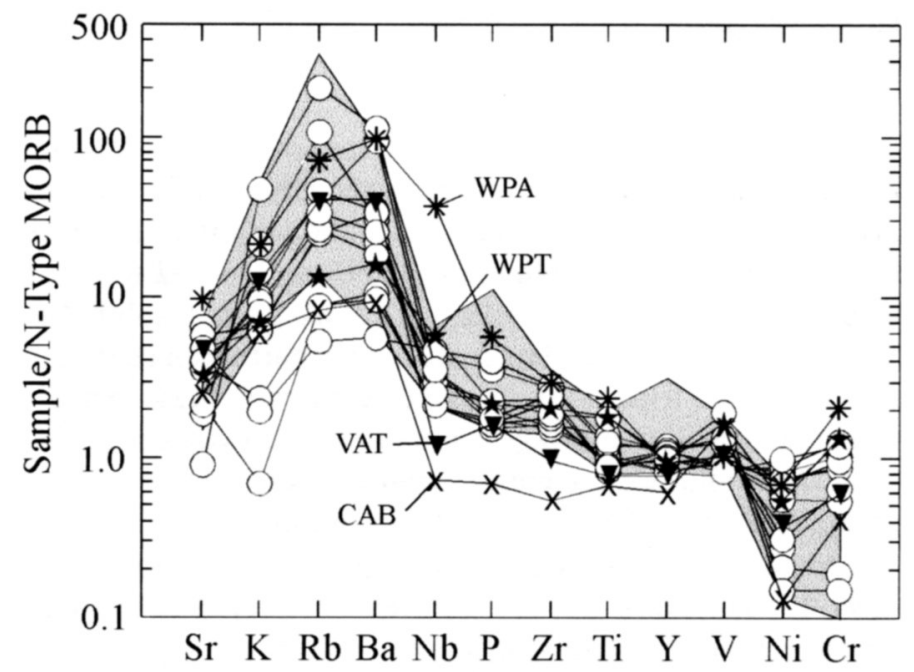

Fig. 6. Multi-element variation diagram to illustrate that mafic volcanic rocks from the Clyburn Brook area are transitional between the average within-plate tholeiite and volcanic-arc tholeiite from Pearce (1982). Data are normalized to average mid-ocean ridge basalt from Pearce (1982), except V value estimated from Shervais (1982). Patterns for average within-plate tholeiitic (WPT), within-plate alkalic basalt (WPA), volcanic arc tholeiite (VAT) and calc-alkalic basalt (CAB) from Pearce (1982) are shown for comparison.

interbedded sedimentary units, suggest that the Ingonish island rhyolite may not be part of the Clyburn Brook formation.

\section{COMPARISON WITH OTHER UNITS}

Raeside and Barr $(1990,1992)$ included rocks of the Clyburn Brook area in the McMillan Flowage Formation, although they noted the difference in metamorphic grade and placed a fault 


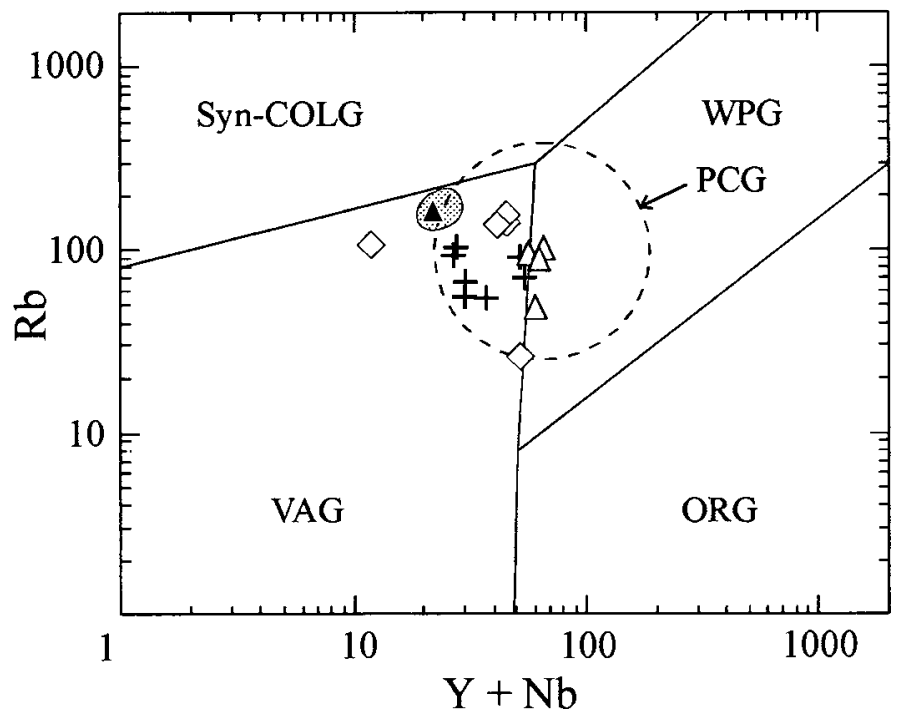

Fig. 7. Felsic samples from the Clyburn Brook area and Ingonish Island plotted on a tectonic setting discrimination diagram with fields after Pearce et al. (1984) and Pearce (1997) and symbols and data sources as in Figure 3. Small shaded field encloses data for six samples from the Cameron Brook Granodiorite (from O'BeimeRyan et al., 1986). Abbreviations: VAG, volcanic-arc granite; ORG, ocean-ridge granite; WPG, within-plate granite; PCG, post-collisional granite.

between the Clyburn Brook area and the rest of the formation to the south. However, the rocks in the Clyburn Brook area also differ lithologically from those of the McMillan Flowage Formation. The McMillan Flowage Formation is dominated by psammitic and pelitic rocks, with marble and amphibolite layers. The amphibolitic layers are mainly narrow and sill-like, and associated with quartzite and calc-silicate rocks. In addition, the McMillan Flowage Formation lacks evidence for intermediate and felsic metatuffaceous rocks that are a major component of the Clyburn Brook formation.

More recent workers (Lynch and Tremblay, 1992; Lin, 1992, 1993, 1995; Lynch et al., 1995) correlated rocks in the Clyburn Brook area with Silurian metavolcanic units of the Aspy terrane. The geographically closest such unit is the Money Point Group (Fig. 1), which consists of metasedimentary $(70 \%)$ and metavolcanic (30\%) rocks (Macdonald and Smith, 1980; Wunapeera, 1992). The metavolcanic rocks are mainly mafic schists, interpreted to represent metamorphosed volcaniclastic rocks and basalts, with minor felsic schist (meta-rhyolite). Overall, the samples from the Clyburn Brook area show chemical similarity to the Money Point Group, although the Money Point samples are even more bimodal, with felsic rocks containing higher $\mathrm{SiO}_{2}$ and generally more evolved in composition (Fig. 3a, b). However, the samples are similarly subalkalic,

Fig. 8. Multi-element variation diagram to illustrate chemical variation in the rhyolitic samples from the (a) Clyburn Brook formation (diamonds), (b) Ingonish Island (volcanic samples are open triangles, felsic dyke sample is represented by black triangles), and (c) Money Point Group (crosses). Data in (c) are from Wunapeera (1992). Data are normalized relative to the average A-type granite of Whalen et al. (1987), and the average felsic I-type granite (star
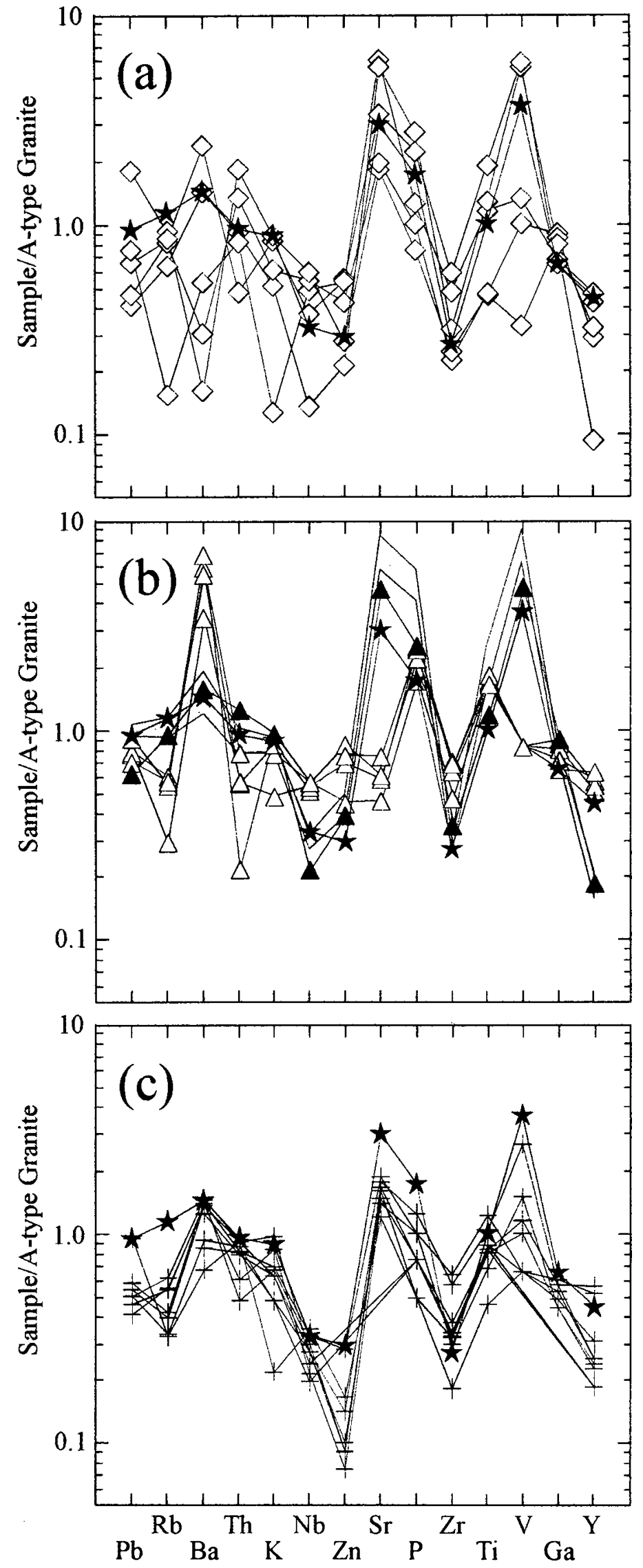

symbol) of Whalen et al., 1987) is shown for comparison on all three diagrams. The shaded field on (b) encloses six samples from the Cameron Brook Granodiorite (O'Beirne-Ryan et al., 1986). 
and mafic samples plot in similar fields on ternary discrimination diagrams (Fig. 4a, b). They also appear to be tholeiitic, although some samples are more evolved to higher $\mathrm{TiO}_{2}$ contents (Figs. 5, 9). They show a similar pattern on the multielement variation diagram (Fig. 6), intermediate between volcanic arc and within-plate tholeiite.

Although higher in $\mathrm{SiO}_{2}$, felsic rocks of the Money Point Group tend to have lower $\mathrm{Y}+\mathrm{Nb}$ values than the Clyburn Brook and Ingonish Island samples, and hence to plot farther into the volcanic arc field on the $\mathrm{Rb}-\mathrm{Y}+\mathrm{Nb}$ discrimination diagram (Fig. 7). They are chemically similar to the average felsic Itype granite (Fig. 8c).

Overall, the chemical data suggest that the Clyburn Brook formation is similar but not identical to the Money Point Group. The similarity suggests that the two units may be of similar age; most workers agree that the Money Point Group and other metavolcanic/metasedimentary units throughout northern and western Cape Breton Island, including the Sarach Brook and Jumping Brook metamorphic suites (Fig. 1), are OrdovicianSilurian in age (Barr and Jamieson, 1991; Lin, 1993). However, reliable age data are needed from the Clyburn Brook formation to confirm this interpretation.

The felsic dyke in the Ingonish Island rhyolite differs chemically from the rhyolite, and lack of petrographic evidence for metamorphism suggests that it may be younger. The analyzed sample is chemically similar to samples from the Cameron Brook Granodiorite (Figs. 7, 8b), which suggests that the dyke (and others like it on Ingonish Island and in the Clyburn Brook area) may be related to the granodiorite. If so, this correlation confirms that the Ingonish Island rhyolite is older than ca. $402 \mathrm{Ma}$, and suggests that the Cameron Brook Granodiorite may have caused the thermal metamorphism evident in the Ingonish Island samples. Alternatively, intrusion of the ca. 375 Ma Black Brook Granitic Suite (Fig. 2) may have caused contact metamorphism in the Ingonish Island area. However, if the correlation of the dykes with the ca. $402 \mathrm{Ma}$ Cameron Brook Granodiorite is correct, then their lack of metamorphism shows that the ca. 375 Ma Black Brook Granitic Suite was not repsonsible for the contact metamorphism in the host rhyolite.

\section{Discussion and conclusions}

The Ingonish Island rhyolite was contact metamorphosed, probably by intrusion of the Cameron Brook Granodiorite, but in contrast to the Clyburn Brook formation, shows little evidence of regional metamorphism. As described above, the two units also show lithological and petrological differences which indicate somewhat different histories. Hence it is suggested that the Ingonish Island rhyolite should not be included in the Clyburn Brook formation.

On the basis of petrological data, Barr and Jamieson (1991) suggested that the metavolcanic-metasedimentary units in the Aspy terrane, including the Money Point Group and Sarach Brook and Jumping Brook metamorphic suites (Fig. 1), represent a volcanic arc setting. Lin (1993) suggested that the data are consistent with either an arc or a back-arc environment. The presence of felsic volcanic rocks indicates that classic

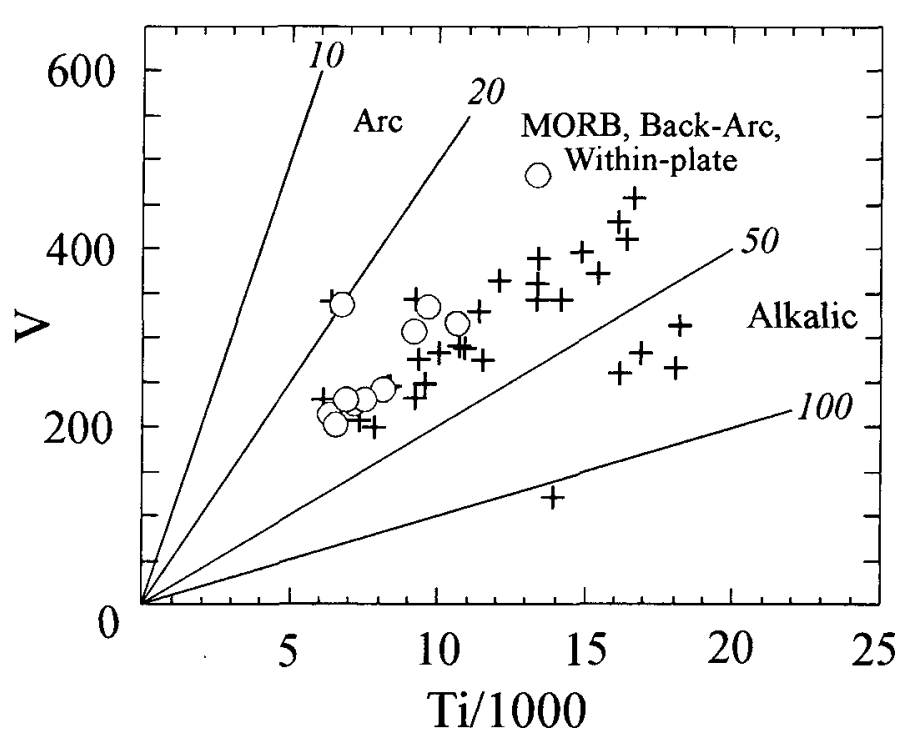

Fig. 9. Plot of $\mathrm{V}$ against $\mathrm{Ti}$ for mafic samples (less than $54 \%$ $\mathrm{SiO}_{2}$ ), with fields from Shervais (1982) and symbols as in Figure 3. Abbreviation: MORB, mid-ocean ridge basalt.

back-arc settings containing oceanic crust, such as the Sea of Japan and Scotia Sea (Wilson, 1989), are not a likely analog. A more likely analog is a zone of extension within or behind a volcanic arc built on continental crust, such as the Taupo volcanic zone in New Zealand (Cole et al., 1995). The Taupo volcanic zone occurs behind part of the Taupo-Hikurangi arc-trench system in an oblique subduction zone, and may provide a reasonable analogy for what was happening in the northern Appalachian orogen during the Silurian (O'Brien et al., 1991; Lin et al., 1994). In New Zealand, this tectonic setting has resulted in a varied assemblage of volcanic rocks, ranging from basalt to rhyolite, and including voluminous silicic volcanic rocks in localized areas, comparable to the volcanic-sedimentary units in Cape Breton Island such as the Clyburn Brook formation. Deformation and metamorphism apparently occurred in the Late Silurian-Early Devonian as a result of compression of the arc and back-arc systems, interpreted to have resulted from collision with the Bras d'Or terrane to the south and possibly the Blair River inlier to the north (Lin et al., 1994; Lin, 1995; Barr et al., 1995).

Including the Clyburn Brook formation in the Aspy terrane requires modification of the terrane model of Barr and Raeside (1989), because they placed the terrane boundary north of the area. However, as also noted by Barr et al. (1995) and Yaowanoiyothin and Barr (1991), a protracted history of complex faulting and Devonian plutonism in this area makes terrane boundary designation speculative.

\section{ACKNOWLEDGements}

The field mapping that formed the basis for this study was funded by the Geological Survey of Canada and NSERC research grants to the authors. We thank Alan Macdonald and Chris White for their contributions to field work. We acknowledge the important contributions made by Shoufa Lin toward our further understanding of the area, and thank him 
for stimulating discussions, and for contributing some of his samples for analysis.

We thank reviewers Shoufa Lin and Brendan Murphy, and editor Graham Williams, for their helpful suggestions.

BARR, S.M. and JAmieson, R.A. 1991. Tectonic setting and regional correlation of Ordovician-Silurian rocks of the Aspy Terrane, Cape Breton Island, Nova Scotia. Canadian Journal of Earth Sciences, 28, pp. 1769-1779.

BARR, S.M. and RAeside, R.P. 1989. Tectonostratigraphic divisions in Cape Breton Island, Nova Scotia: Implications for the configuration of terranes in the northern Appalachian Orogen. Geology, 17, pp. 822-825.

----- 1994. Discussion of the paper "Relationship between the Aspy and Bras d'Or terranes in the northeastern Cape Breton Highlands, Nova Scotia", by Shoufa Lin. Canadian Journal of Earth Sciences, 31, pp. 1384-1385.

Barr, S.M., Jamieson, R.A., and Raeside, R.P. 1992. Geology, northern Cape Breton Island, Nova Scotia. Geological Survey of Canada, Map 1752A, 1:100,000.

Barr, S.M., Raeside, R.P., Mrller, B.V., and White, C.E. 1995. Terrane evolution and accretion in Cape Breton Island, Nova Scotia. In Current Perspectives in the Appalachian-Caledonian Orogen. Edited by J.P. Hibbard, C.R. van Staal, and P.A. Cawood. Geological Association of Canada, Special Paper 41 , pp. $391-407$.

Chen, Y.D., Lin, S., and van StaAl, C.R. 1995. Detrital zircon geochronology of a conglomerate in the northeastern Cape Breton Highlands: Implications for the relationships between terranes in Cape Breton Island, the Canadian Appalachians. Canadian Journal of Earth Sciences, 32, pp. 216-223.

Cole, J.W., Darby, D.J., and Stern, T.A. 1995. Taupo volcanic zone and central volcanic region, backarc structures of North Island, New Zealand. In Backarc basins: Tectonics and magmatism. Edited by Brian Taylor. Plenum Press, New York. pp. 1-28.

Dunning, G.R., BARR, S.M., Raeside, R.P., and Jamieson, R.A. 1990. U-Pb zircon, titanite and monazite ages in the Bras d'Or and Aspy terranes of Cape Breton Island, Nova Scotia. Implications for magmatic and metamorphic history. Geological Society of America Bulletin, 102, pp. 322-330.

KePPIE, J.D. and HallidaY, A.N. 1986. Rb-Sr isotopic data from three suites of igneous rocks, Cape Breton Island, Nova Scotia. Maritime Sediments and Atlantic Geology, 22, pp. 162-171.

Keppie, J.D., Dostal, J., Murphy, J.B., and Cousens, B.L. 1997. Paleozoic within-plate volcanic rocks in Nova Scotia (Canada) reinterpreted: isotopic constraints on magmatic source and palaeocontinental reconstructions. Geological Magazine, 134, pp. 425-447.

LN, S. 1992. The stratigraphy and structural geology of the southeastern Cape Breton Highlands National Park and its implications for the tectonic evolution of Cape Breton Island, Nova Scotia, with emphasis on lineations in shear zones. Ph.D thesis, University of New Brunswick, 240 p.

-_- 1993. Relationship between the Aspy and Bras d'Or "terranes" in the northeastern Cape Breton Highlands, Nova Scotia. Canadian Journal of Earth Sciences, 30, pp. 1773-1781.

----1 1995. Structural evolution and tectonic significance of the Eastern Highlands shear zone in Cape Breton Island, the Canadian Appalachians. Canadian Journal of Earth Sciences, 32, pp. 545-554.

Lin, S., van StaAl, C.R., and Dube, B. 1994. Promontory-promontory collision and tear faulting in the Canadian Appalachians. Geology, 22, pp. 897-901.
LrNCH, G. 1996. Tectonic burial, thrust emplacement, and extensional exhumation of the Cabot nappe in the Appalachian hinterland of Cape Breton Island, Canada. Tectonics, 15, pp. 94105.

LyNCH, J.V.G. and Tremblay, C. 1992. Imbricate thrusting, reverse-oblique shear, and ductile extensional shear in the Acadian Orogen, central Cape Breton Highlands, Nova Scotia. Current Research, Part D, Geological Survey of Canada, Paper 92-1D, pp. 91-100.

Lynch, G., Barr, S.M., Houlahan, T., and Giles, P. 1995. Geological compilation, Cape Breton Island, Nova Scotia. Geological Survey of Canada, Open File 3159, scale 1:250,000.

Macdonald, A.S. and Smith, P.K. 1980. Geology of the Cape North area, northern Cape Breton Island, Nova Scotia. Nova Scotia Department of Mines and Energy, Paper 80-1, 60 p.

Meschede, M. 1986. A method of discriminating between different types of mid-ocean ridge basalts and continental tholeiites with the Nb-Zr-Y diagram. Chemical Geology, 56, pp. $207-$ 218.

MiYASHIRO, A. 1974. Volcanic rock series in island arcs and active continental margins. American Journal of Science, 274, pp. 321-355.

O'Berrne-Ryan, A.M., BarR, S.M., and Jamieson, RA. 1986. Contrasting petrology and age of two megacrystic granitoid plutons, Cape Breton Island, Nova Scotia. In Current Research, Part B, Geological Survey of Canada, Paper 86-1B, pp. 29-38.

O'Brien, B.H., O'Brien, S.J., and Dunning, G.R. 1991. Silurian cover, Late Precambrian-Early Ordovician basement and the chronology of Silurian orogenesis in the Hermitage Flexure (Newfoundland Appalachians). American Joumal of Science, 291, pp. 760-799.

Pearce, J.A. 1982. Trace element characteristics of lavas from destructive plate boundaries. In Andesites: Orogenic Andesites and Related Rocks. Edited by R.S Thorpe. Wiley-Interscience, New York, pp. 525-548.

1997. Sources and settings of granitic rocks. Episodes, 19, pp. 120-125.

Pearce, J.A. and Cann, J.R. 1973. Tectonic setting of basic volcanic rocks determined using element analyses. Earth and Planetary Science Letters, 19, pp. 290-300.

Pearce, J.A., Harris, N.B.W., and Tindle, A.G. 1984. Trace element discrimination diagrams for the tectonic interpretation of granitic rocks. Journal of Petrology, 25, pp. 956-983.

RAESIDE, R.P. and BARR, S.M. 1990. Geology and tectonic development of the Bras d'Or suspect terrane, Cape Breton Island, Nova Scotia. Canadian Journal of Earth Sciences, 27, pp. 1371-1381.

RAESIDE, R.P. and BARR, S.M. 1992. Geology of the northern and eastern Cape Breton Highlands, Cape Breton Island, Nova Scotia. Geological Survey of Canada, Paper 89-14, 39 p.

Shervals, J.W. 1982. Ti-V plots and the petrogenesis of modern and ophiolitic lavas. Earth and Planetary Science Letters, 59, pp. 101-118.

van Der GaAg, J., Schenk, P., and von Bitrer, P. 1996. Chemosynthetic tube worms concentrated around hydrothermal mounds over volcanic rocks, Gays River Formation, basal Windsor Group, Ingonish Island, Cape Breton. Atlantic Geology, 32, p. 88.

Whalen, J.B., Currie, K.L., and Chappell, B.W. 1987. A-type granites: geochemical characteristics, discrimination, and petrogenesis. Contributions to Mineralogy and Petrology, 95 , pp. $407-419$. 
WIEBE, R.A. 1972. Igneous and tectonic events in the northeastern Cape Breton Island, Nova Scotia. Canadian Journal of Earth Sciences, 9, pp. 1262-1277.

WiLson, M. 1989. Igneous Petrogenesis: a global tectonic approach. Unwin Hyman Limited, United Kingdom, 466 p.

WiNCHESTER, J.A. and F LOYD, P.A. 1977. Geochemical discrimination of different magma series and their differentiation products using immobile elements. Chemical Geology, 20, pp. 325-343.

\section{Appendix A. Brief petrographic descriptions of analyzed samples}

Clyburn Brook formation - mafic samples:

1. SB86-3104. Metabasalt. Dominated by actinolite, plagioclase $\left(\mathrm{An}_{25}\right)$, chlorite, and opaque minerals. Foliated.

2. CW86-3616B. Metabasalt. Mainly epidote, chlorite, and albite. Patchy remnant broken epidotized phenocrysts.

3. CW86-3618B. Banded mafic metatuff. Abundant actinolite with epidote, chlorite, quartz, and plagioclase (relict crystals $\mathrm{An}_{44}$ ). Sheared.

4. CW86-3621. Metabasalt. Relict intergranular texture replaced by actinolite, epidote, biotite, and albite. Unfoliated.

5. CW86-3625. Mafic metatuff? Protomylonitic fabric dominated by schistose chlorite and muscovite and interstitial albite and quartz. Abundant carbonate.

6. CW86-3629. Metabasalt. Relict f.g. intergranular texture, replaced by actinolite, chlorite, epidote, and albitic plagioclase. Unfoliated.

7. CW86-3640. Metabasalt. Recrystallized texture dominated by well-foliated actinolite, biotite, and albitic plagioclase, with minor quartz. Relict porphyritic texture.

8. CW86-3641. Metabasalt. Similar to CW86-3641.

9. RR86-2582. Metabasalt? Highly altered, with abundant plagioclase, epidote, and actinolite and relict subophitic texture.

10. RW090. Mafic metatuff? Plagioclase $\left(\mathrm{An}_{30}\right)$ porphyroclasts in a well-foliated matrix of mainly chlorite, epidote, carbonate, and sericite.

11. SL32. Basaltic to andesitic crystal lithic metatuff. Plagioclase, quartz, and lithic clasts in a foliated groundmass of sericite, epidote, chlorite, and actinolite.

Clyburn Brook formation - intermediate samples:

12. SB86-3101. Porphyritic metadacite. Network of plagioclase laths with abundant subhedral epidote and biotite and less abundant sericite. Relict plagioclase phenocrysts.

13. SL91-1. Metatuff. Fine-grained foliated feldspar laths, chlorite, and sericite, with scattered cubes of pyrite.
Wunapeera, A. 1992. The geology of the Cape North and Money Point groups, northern Cape Breton Highlands, Nova Scotia. M.Sc. thesis, Acadia University, Wolfville, Nova Scotia, 293 p.

YaOWANOIYOTHIN, W. and BARR, S.M. 1991. Petrology of the Black Brook granitic suite, Cape Breton Island, Nova Scotia. Canadian Mineralogist, 29, pp. 499-515.

Editorial Responsibility : Graham L. Williams

Clyburn Brook formation - felsic samples:

14. SL39. Metarhyolite. Phenocrysts of plagioclase in a f.g. granular groundmass of quartz and feldspar. Abundant muscovite.

15. SB86-3103. Metarhyolite. Fine-grained granoblastic quartz and feldspar dusted with epidote, sericite, biotite, garnet, and opaque phases. Scattered relict plagioclase phenocrysts.

16. CW86-3643. Felsic metatuff. Rhyolitic clasts and abundant feldspar and recrystallized quartz phenocrysts in a microcrystalline granular to flow-aligned groundmass with minor biotite and muscovite.

17. RR86-2577. Rhyolite. Quartz, plagioclase, and sanidine phenocrysts in a microgranophyric groundmass. Minor biotite and sericite.

18. RR86-2579. Metarhyolite. Deformed quartz, plagioclase, and sanidine phenocrysts in a well-foliated groundmass, with abundant muscovite.

Ingonish Island samples:

19. RR86-2630. Pink rhyolitic dyke. Scattered anorthoclase and plagioclase phenocrysts in a trachytic groundmass; abundant igneous-looking biotite.

20. RR86-2631. Rhyodacite. Cryptocrystalline groundmass with sparse anorthoclase phenocrysts and dusted with opaque minerals.

21. RR86-2632. Rhyodacitic lithic tuff. Mainly cryptocrystalline, flow-aligned groundmass, with irregular coarsergrained patches. Abundant mainly aligned, flakes of muscovite. Dusted with opaque minerals.

22. RR86-2634. Rhyodacite. Strongly foliated cryptocrystalline groundmass with scattered phenocrysts of feldspar and recrystallized quartz aggregates. Original flowfoliation accentuated by deformation.

23. RR86-2638. Rhyodacite. Felted f.g. groundmass with sparse alkali feldspar phenocrysts. 